\title{
Strategic Drivers of Software Quality: Beyond External and Internal Software Quality
}

Ronan Fitzpatrick

Technological University Dublin, Ronan.fitzpatrick@tudublin.ie

Follow this and additional works at: https://arrow.tudublin.ie/scschcomcon

Part of the Engineering Commons

\section{Recommended Citation}

Fitzpatrick, R. (2001). Strategic drivers of software quality: beyond external and internal software quality. Second Asia-Pacific Conference on Quality Software, Proceedings of APAQS 2001, Hong Kong. doi:10.1109/APAQS.2001.990003

This Article is brought to you for free and open access by the School of Computer Sciences at ARROW@TU Dublin. It has been accepted for inclusion in Conference papers by an authorized administrator of ARROW@TU Dublin.

For more information, please contact arrow.admin@tudublin.ie, aisling.coyne@tudublin.ie, gerard.connolly@tudublin.ie. 


\title{
Strategic Drivers of Software Quality: Beyond External and Internal Software Quality
}

\author{
Ronan Fitzpatrick \\ School of Computing, \\ Dublin Institute of Technology, Kevin Street, Dublin 8, Ireland. \\ Tel: + 35314024835 Fax: + 35314024994 \\ Email: rfitzpatrick@maths.kst.dit.ie
}

\begin{abstract}
Software quality is often considered in terms of the contractual requirements between the supplier and acquirer as described in ISO/IEC 12207 and focuses on software life cycle processes. However, beyond these processes acquirer organisations need to address other issues like complying with new legislation, securing return on investment, and achieving competitive support from their new software investments. Supplier organisations also have issues that they must manage. This paper addresses all of these issues and presents eleven issues, which it calls strategic drivers. Then, using the SOFTWARE QUALITY STAR, builds a new conceptual model where each strategic quality driver is defined and explained.

Keywords - quality characteristics; external quality factors; internal quality factors; procurer; producer; strategic quality drivers; Software Quality - Strategic Driver Model (SQ_SDM).

\section{Introduction}

The study of software quality is often influenced by studies of software quality factors [1], [2] or by desire to secure certification. The principal focus of the studies has been to create products, which demonstrate high levels of usability and other technical excellence while the principal focus of the certification endeavours has been to demonstrate supplier organisational maturity as a software development organisation. This in turn has provided confidence to the acquirer (procurer) community who need to enter into contracts with supplier (producer) organisations. So, from the acquirer's perspective software quality has been limited to usability excellence, technical excellence and to the supplier organisation's ability to deliver this excellence. However, a number of developments are forcing a change in perspectives. For example, as the information technology sector expands, it has had to be subjected to the rigors of the law and new
\end{abstract}

legislation has been introduces which software products must comply with. There is also and increasing awareness of the need to secure value for money from IT investments. The growth and demands of e-commerce are resulting in demands from software acquirers for products that will support their competitive position. So, it is appropriate to review strategic considerations that influence software acquirers in order to determine a broader understanding of what actually contributes to software quality. This is the aim of this paper and to this end the paper defines a set of strategic quality drivers for software products. The aim of the paper is to clarify for procurer organisations a new paradigm of software quality. Section 2 presents an overview of current acquirer's perception of software quality, defines strategic drivers and identifies eleven new strategic quality drivers, which influence both the procurer and the producer. This section introduces a new Software Quality - Strategic Driver Model (SQ_SDM). Section 3 and 4 define and explain each of the strategic drivers identified in the model and present summary tables for both the procurer and producer perspectives.

\section{Strategic drivers of software quality}

From the software acquirer's perspective, the quality characteristics of a software product are generally described in terms of external and int ernal quality factors [3]. These can be easily mapped respectively to the usability excellence and to the technical excellence of the product. In terms of the actors involved these relate to the quality perspectives of the users (external/usability) and to the quality perspectives of IS technical support and maintenance professionals (internal/technical). However, there is a third actor who contributes to this MIS triad. This is the procurer (representing strategic management) who also has a perspective of software quality and which includes more than external and internal quality factors. In this new paradigm this paper shows that all of the traditional external quality factors are collectively the usability of the 
software product while all of the internal quality factors are collectively the supportability of the software product. Typically that would be the extent of the study of software quality insofar as it applies to information systems. However, this paper demonstrates that there are other issues.

Software quality is a measure of excellence, which, is achieved through a number of strategic quality drivers. Strategic drivers are defined in this paper as a set of interrelated issues, which must be managed (planned, organised, controlled and directed) in order to achieve success in a specific domain in a specified context. For the purpose of this paper the specific domain is software quality and the specified context is Information Systems acquisition. In this paper, these strategic quality drivers present a new paradigm for software quality and provide strategic focus for software acquirers. They are of a higher, all embracing, order than traditional quality factors and focus on strategic business excellence in addition to product technical excellence. This paper presents six strategic quality drivers which impact the acquirer (procurer) of software. They relate to ensuring that the software is supportable and maintainable by IS technical professionals: to ensuring that the software is usable by the workforce; to aligning the software product and the organisation's business processes; to being satisfied that the software product complies with the organisation's legal obligations; to securing value for money; and, to assisting the organisation to sustain its competitive position. The paper names these strategic quality drivers as Technical excellence (Supportability), User acceptance (Acceptability), Corporate alignment (Alignability), Statutory conformance (Conformability), Investment efficient (Affordability), and Competitive support (Superiority). The paper also presents five strategic quality drivers which impact the supplier (producer) of software. These five relate to ensuring that the procurer's quality requirements are managed at all phases of the evolving software product; best quality assurance development standards and practice; the supplier organisation's knowledge and expertise of the procurer organisation's business processes; certification of the producer organisation's capability of creating quality software; and, to the competitive standing of a software producer compared with competitor software organisations. The paper names these strategic quality drivers as Quality management (Direction). Development excellence (Organisation), Domain speciality (Qualification), Corporate accreditation (Certification), and Competitive excellence (Domination). All of the strategic quality drivers are illustrated in the Software Quality - Strategic

Driver Model (SQ-SDM) in figure 1.

\section{Software Q uality - Strategic Driver Model}

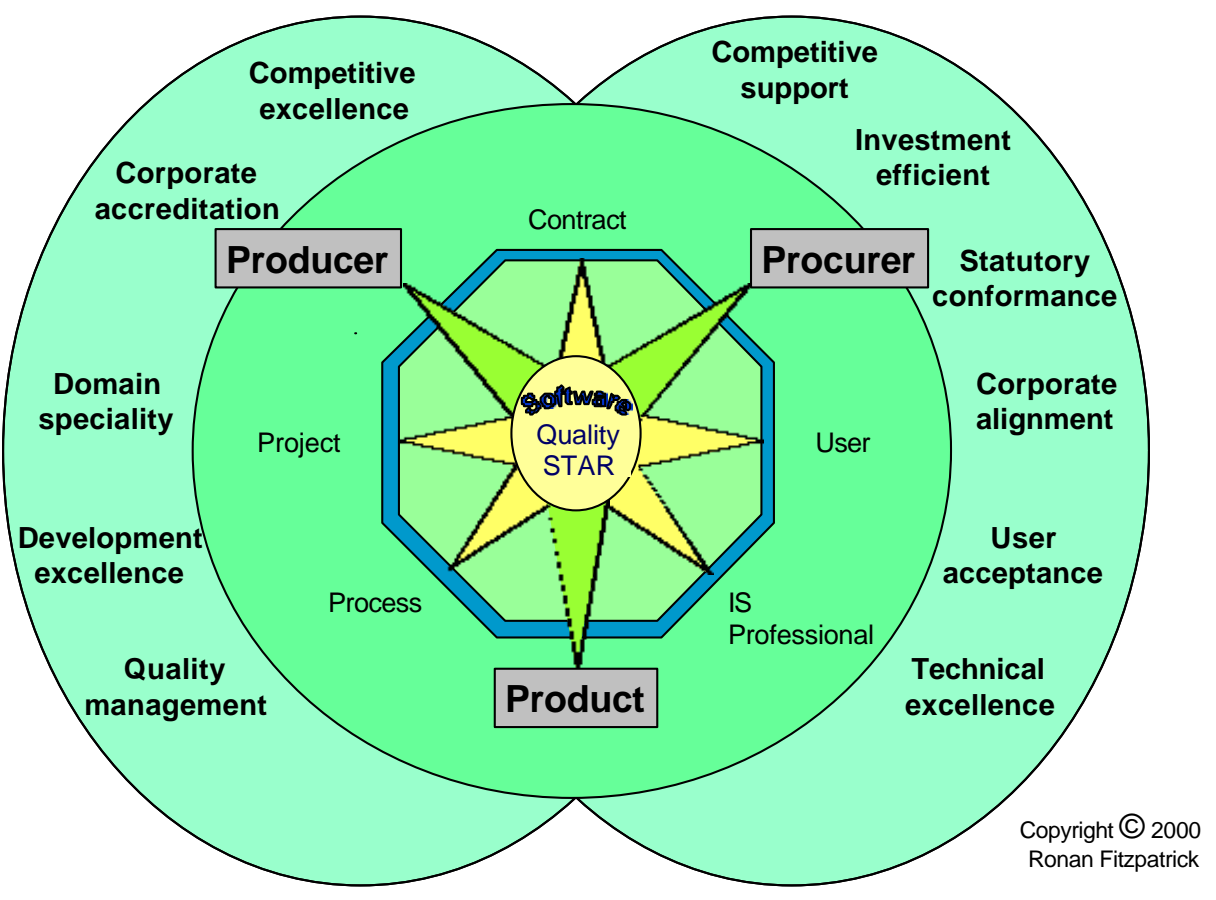

Figure 1 - Software Quality - Strategic Driver Model (SQ -SDM) 
Most of these issues are well researched although they are not normally perceived as strategic quality drivers. Neither are they perceived as being interrelated. Industry understanding of some of these drivers like, Statutory conformance, is only now being researched as a result of governments introducing legislation. This paper names the strategic drivers and presents them in one model so that the perspectives of the procurer and the producer can be focused in order to achieve software products of the highest quality.

\section{Procurer software quality strategic drivers explained}

The six strategic quality drivers, which provide focus for forming an acquirer's perspective of software quality, are explained in this section. The explanations include a description and definition of each strategic quality driver and indicate the quality considerations, which are appropriate to that strategic driver.

\subsection{Technical excellence (Supportability)}

Technical excellence is concerned with ensuring that the software is serviceable and maintainable by IS professionals and is defined as the strategic quality driver for excellence in software product support. It embraces all of the quality fact ors of the software product (external, as in section 3.2, and internal - maintainability, testability, flexibility, reusability and portability) and the ability of the IS professional to support users in their use of the product. In keeping with ISO/IEC 12207 [4] the software product consists of all designs, programs, procedures, supporting documentation and data. Hewlett-Packard in their FURPS quality factors model consider serviceability to combine the ability to extend the program, adapt and servi ce it. Ghezzi et al. [3] divide maintenance into three categories: corrective, adaptive and perfective. The combination of these two - service and maintenance - influences the IS professionals technical acceptance of the software and as a procurer's strategic quality driver they are collectively software supportability.

\subsection{User acceptance (Acceptability)}

User acceptaance is concerned with ensuring that the software is acceptable to the user community and that it is usable by them. It is defined as the strategic quality driver for excellence at the user interface and has two focuses. First, this strategic quality driver embraces all of the factors that have heretofore been described as external quality factors, that is, those factors that impact the user. According to Fitzpatrick and Higgins [5] these include, suitability, installability, functionality, adaptability, ease-of- use, learnability, interoperability, reliability, safety, security, correctness and efficiency. Second, it embraces the extent to which the corporate alignment of business processes addressed by the software, empowers the user. The combination of these two - external quality factors and business processes - influences user acceptance of the software and as a procurer's strategic quality driver they are collectively software Acceptability.

\subsection{Corporate alignment (Alignability)}

Corporate alignment is concerned with aligning the software product and the organisation's business strategy. There is a broad range of research literature relating to alignment where the principal authors are Henderson and Venkatraman [6]. The expression strategic is normally used to describe alignment. Henderson and Venkatraman emphasise that alignment is achieved through the strategic integration of the IT domain with the business domain. For the IT domain, applications, data, the user interface and communications all have to be harmonised with the business. For the business domain, both business strategy (External integration) and organisational infrastructure and processes (Internal integration) must be addressed. This alignment will include functional alignment of the different corporate functions. The reader will appreciate that alignment must embrace all levels (strategic, tactical and operational) and all functions of the organisational pyramid. For example, at a strategic level Eardley [7] states that a strategic vision and the organisation's current position must be considered. He continues that the alignment strategy should be sufficiently flexibility to accommodate changes in both domains. Further down the organisational pyramid business processes might need to be re-engineered to suit the strategic vision while even further down the pyramid it might be necessary to focus on the data structures that are used for the operational achievement of the strategic vision. Corporate alignment is defined as the strategic quality driver for IT excellence in business practice.

\subsection{Statutory conformance (Conformability)}

Statutory conformance (Conformability) is concerned with being satisfied that the software product complies with the organisation's legal obligations and is defined as the strategic quality driver for excellence with legal compliance.

Conformability is about ensuring that the quality of the software (eg adaptability, safety, learnability and security) conforms to the force of law at national and international level. Typically, the laws include the EU legal directive for display screen equipment, The Data Protection Act and Intellectual Property Rights legislation, especially patent, copyright, trademarks and look and feel. 


\begin{tabular}{|c|c|c|}
\hline STRATEGIC DRIVER & DESCRIPTION AND DEFINITION & QUALITY FOCUS \\
\hline $\begin{array}{l}\text { Competitive } \\
\text { support }\end{array}$ & $\begin{array}{l}\text { The software's ability to assist the } \\
\text { organisation to sustain its competitive } \\
\text { position. }\end{array}$ & \multirow[t]{2}{*}{ - Value-chain quality benefits } \\
\hline Superiority & $\begin{array}{l}\text { Defined as the strategic quality driver for } \\
\text { competitive support. }\end{array}$ & \\
\hline $\begin{array}{l}\text { Investment } \\
\text { efficient } \\
\text { Affordability }\end{array}$ & $\begin{array}{l}\text { Securing value for money. } \\
\text { Defined as the strategic quality driver for } \\
\text { excellence in IT Investment. }\end{array}$ & $\begin{array}{l}\text { - Contemporary techniques to } \\
\text { evaluate IT investment }\end{array}$ \\
\hline $\begin{array}{l}\text { Statutory } \\
\text { conformance }\end{array}$ & $\begin{array}{l}\text { Being satisfied that the software product } \\
\text { complies with the organisation's legal } \\
\text { obligations. }\end{array}$ & \multirow{2}{*}{$\begin{array}{l}\text { - EU Display screen directive } \\
\text { - Data Protection Act } \\
\text { - Intellectual property rights }\end{array}$} \\
\hline Conformability & $\begin{array}{l}\text { Defined as the strategic quality driver for } \\
\text { excellence with legal compliance. }\end{array}$ & \\
\hline $\begin{array}{l}\text { Corporate } \\
\text { alignment }\end{array}$ & $\begin{array}{l}\text { Aligning the software product and the } \\
\text { organisation's business strategy. }\end{array}$ & \multirow[t]{2}{*}{$\begin{array}{l}\text { - Aligning the IT domain and the } \\
\text { business domain }\end{array}$} \\
\hline Alignability & $\begin{array}{l}\text { Defined as the strategic quality driver for } \\
\text { IT excellence in business practice. }\end{array}$ & \\
\hline $\begin{array}{l}\text { User } \\
\text { acceptance }\end{array}$ & $\begin{array}{l}\text { Ensuring that the software is acceptable } \\
\text { to the user community and that it is } \\
\text { usable by them. }\end{array}$ & \multirow{2}{*}{$\begin{array}{l}\text { - Usability attributes of the } \\
\text { software product } \\
\text { - Process alignment }\end{array}$} \\
\hline Acceptability & $\begin{array}{l}\text { Defined as the strategic quality driver for } \\
\text { excellence at the user interface. }\end{array}$ & \\
\hline $\begin{array}{l}\text { Technical } \\
\text { excellence }\end{array}$ & $\begin{array}{l}\text { Supportability is concerned with } \\
\text { ensuring that the software is serviceable } \\
\text { and maintainable by IS professionals. }\end{array}$ & \multirow[t]{2}{*}{$\begin{array}{l}\text { - Complete set of software quality } \\
\text { factors }\end{array}$} \\
\hline Supportability & $\begin{array}{l}\text { Defined as the strategic quality driver for } \\
\text { excellence in software product support. }\end{array}$ & \\
\hline
\end{tabular}

Figure 2 - Strategic Quality Drivers defined - Procurer

Conformability is not to be confused with business processes like VAT returns, social security deductions or national pension plan deductions, that comply with government directives or statutory instruments. Business processes like these are part of alignability.

\subsection{Investment efficient (Affordability)}

Investment efficient (Affordability) is the strategic driver that focuses on securing value for money. Establishing the efficiency of IT investments is the responsibility of accounting and investment professionals. Early IT investments relied on traditional evaluation techniques like
Return on Investment (RoI), Net Present Value (NPV) and Internal Rate of Return (IRR) but research has shown these techniques to be inappropriate for the special nature of IT investments. According to Weill and Olson [8] management began to ask questions like "Are the computerised systems contributing in a manner that was originally intended?", "Have they secured value for money?", "What is the business value of computers?" and "What is the impact of the level of investment in IT on a firm's performance?" More recently, what have become known as contemporary techniques, and which focus on a set of IT evaluation criteria, have proven more appropriate. Popular contemporary techniques include Information Economics (IE), Return on management (ROM), The Kobler Unit approach, SESAME and The Application 
Transfer Team (ATT). Typical of the management criteria which address the IT focus that are evaluated by these contemporary techniques are Tangible Benefit, Intangible Benefit, Knock-on Benefit, Life Span, IT Risk, Strategic Match, IS Match and Portfolio. Affordability is the strategic quality driver for excellence in IT investment.

\subsection{Competitive support (Superiority)}

Competitive supportr relates to the software's ability to assist the acquirer organisation to sustain its competitive position and is defined as the strategic quality driver for Competitive support.

This quality driver focuses the acquirer's attention on the "opportunity for improved profitability" that the new software product presents. This view is supported by Robson [9] who states, in relation to competitive advantage, "So, what good does come about? Competitive advantage, no, but improved profitability, yes". She continues that competitive advantage might not be achieved but competitive disadvantage will follow if proactive approaches are not employed. For this reason, Competitive support is more descriptive of this Strategic Quality Driver. Opportunities for improved profitability are available throughout Porter's entire Value-Chain [10] [11] and every acquirer organisation will need to complete its own industry specific analysis in order to identify the opportunities unique to them. Based on [9, p187], typical of the categories that might be analyses are: Supplier to customer relationships, Distribution channels, Production economies and product life cycles, and Value-added services. The acquirer organisation also needs to be conscious of their customer's perception of them if they do not embrace IT solutions. They also need to be aware of the importance of empowering the employees through IT. For some interesting examples under the headings of Proprietary advantage, One step ahead, Discontinuity, and Implementation the reader is referred to [9].

That concludes the review of the acquirer's perception of strategic quality drivers. Figure 2 tabulates them with the quality focus that is relevant to each.

\section{Producer software quality strategic drivers explained}

The five strategic quality drivers, which provide focus for forming a supplier's perspective of software quality, are explained in this section. The explanations include a description and definition of each strategic quality driver and indicate the quality considerations, which are appropriate to that strategic driver. The reader will understand that these strategic quality drivers are also of special interest to the acquirer and will form the basis of evaluating the producer's capability of creating a quality software product. This set of strategic quality drivers is also of critical importance to the producer organisation when defining their quality vision and philosophy.

\subsection{Quality management (Direction)}

Quality management is concerned with ensuring that the procurer's quality requirements are incorporated at all phases of the evolving software product. It is defined as the strategic quality driver for excellence in assuring software quality and includes quality assurance planning and quality control.

Quality assurance planning, according to ISO/IEC 12207 (1995), involves

- Quality standards, methodologies, procedures, and tools for performing the quality assurance activities (or their references in organisation's official documentation)

- Procedures for contract review and coordination thereof

- Procedures for identification, collection, filing, maintenance and disposition of quality records

- Resources, schedule, and responsibilities for conducting the quality assurance activities

- Selected activities and tasks from supporting processes, such as Verification, Validation, Joint Review, Audit, and problem Resolution.

Quality control is the proactive cyclical revisiting of all of the planned quality assurance activities in order to ensure that quality requirements are being achieved.

The quality characteristics that must be assured by this process are originally specified under clause 5.3.4.1 of ISO/IEC 12207 (1995).

Quality management is the role of the quality manager and ISO/IEC 12207 (1995) requires that "to be unbiased, quality assurance needs to have organisational freedom and authority from persons directly responsible for developing the software product or executing the process in the project".

\subsection{Development excellence (Organisation)}

Development excellence is concerned with ensuring that the software product is created in accordance with best management standards and practice. It is defined as the strategic quality driver for excellence during the project life cycle and includes project management excellence, technical competence and continuous process improvement.

Project management excellence. Through the application of management techniques like planning and controlling the acquirer is reassured of the ability of the supplier to deliver a quality software product. According to ISO/IEC 12207 (1995) the onus is on the supplier to develop and document 
project management plans (section 5.2.4.5) and the supplier shall implement and execute the project management plans (section 5.2.5.1). The Standard recommends that project management planning should address issues like Organisation and environment, Acquirer involvement, Acquirer requirements and quality characteristic, WBS, Resources and contractors, Quality assurance/validation and Verification, Risk management, Licensing, usage and ownership, Tracking, documenting and reporting, and Personnel training. Project control is the cyclical revisiting of these issues to ensure that they progress to plan.

Technical competence. The technical ability of the IS professionals available to the supplier organisation (employed by, contract hired or outsourced) will significantly impact the supplier's ability to create quality software products and deliver them on time and within budget. Typically, technical competence will address IS professional staff qualifications and their experience relevant to the project. To a limited extent this staff's understanding of the business processes being addressed by the new software product is also important in order that they can correctly interpret the requirements specification.

Continuous process improvement. From a development perspective, this is concerned with the review of how a supplier organisation creates quality software products in order to identify shortcomings in their practice. Having identified any shortcomings the supplier organisation will initiate procedures, to improve the original practice with a view to improving the quality of the software product.

\subsection{Domain speciality (Qualification)}

Domain speciality relates to the producer organisation's knowledge and expertise of the procurer organisation's business processes. It is defined as the strategic quality driver for excellent business process understanding.

In order to demonstrate excellence in this software quality driver, the supplier organisation must number among its employees consultants who fully understand the theory and professional practice of the acquirer's business processes. Input from these consultants into the creation of the software product begins at contract tender stage and will continue for the life of the project to beyond final handover.

\subsection{Corporate accreditation (Certification)}

Corporate accreditation relates to the independent certification of the producer organisation's capability of creating quality software products. It is defined as the strategic quality driver of contractor maturity and includes Capability Maturity Model appraisal, ISO 9000 certification and similar accreditations.

Capability Maturity Model appraisal (CMM). The Capability Maturity Model for Software (SW-CMM) is a conceptual structure for managing and developing software products in a disciplined and consistent way [12]. It was developed by the Software Engineering Institute at Carnegie Mellon University in response to a need of the U.S. Department of Defense who required supporting techniques to enable them to evaluate and select competent software contractors. It consists of five maturity levels - Initial, Repeatable, Defined, Managed and Optimizing - each of which contains key process. Organisations are appraised as being of a certain level in this model - the higher their level, the higher their maturity.

ISO 9000 certification. The International Organisation for Standardisation (ISO) have published ISO Standard 9001 [13] and ISO 9000-3 [14] which provide guidelines for best practice for software developer organisations. The national representative organisations of ISO are approved to review and evaluate a software developer's practice and to grant ISO certification if that practice is of a required standard. Those who are certified are allowed dis play a Quality Mark on the promotional literature. In the United Kingdom, Ticket, is the expression used to express this type of certification.

These are the principal categories of certification. However, representative organisations offer similar accreditations which certify their members ability to complete software projects and it is advisable to establish local practice in this regard.

There are extensive practitioner reports of how accreditation policies have contributed to improved software quality. For a recent selection of these the reader is referred to the Proceedings of the Second World Congress for Software Quality [15].

In this category it is also appropriate to consider the producer organisation's quality vision, attitude and philosophy towards of The House of Total Quality Management.

\subsection{Competitive excellence (Domination)}

Competitive excellence relates to the competitive standing or rating of a software producer compared with rival software organisations. It is defined as the strategic quality driver for selecting a suitable producer.

As part of the acquisition process it is normal for an acquirer to identify a number of potential suppliers and to invite them to tender for the software contract. No two potential suppliers will have identical profile. They will have different strengths and weaknesses, so, Competitive excellence profile includes Regional affiliation, Financial capacity, and Experience.

Regional affiliation is concerned with national, regional and international trading agreements or partnerships like the North American Free Trade Agreement (NAFTA) and the 
single market of the European Union, which is achieved through the European Free Trade Association (EFTA). These agreements provide protection for organisations in member states and quite often require tendering organisations to be fully registered and resident in a partner country.

Financial capacity relates to the producer's capability to fund their commitments to the project. For example, projects, especially large scale or safety-critical projects, may require the producer to have independent access to financial resources to ensure that the project does not fail during payment milestones.

Experience is concerned with the producer's past performance with similar type projects. Even though a tenderer may have achieved a high level rating on a maturity model some of the other tenderers, who have the same maturity rating, may have experience of successfully completing a greater number of similar projects.

Competitive excellence is the last of the strategic drivers presented in the $S Q \_S D M$ and it is the one which best illustrates how some drivers are relevant to more than one perspective. For example, Competitive excellence must be worked for, achieved and maintained by the producer yet it is the procurer who may use Competitive excellence as the influencing strategic driver when selecting a suitable producer.

That concludes the explanation of the supplier's five strategic quality drivers. Figure 3 tabulates them with the Quality focus that is relevant to each.

\begin{tabular}{|c|c|c|}
\hline STRATEGIC DRIVER & DESCRIPTION AND DEFINITION & QUALITY FOCUS \\
\hline $\begin{array}{l}\text { Competitive } \\
\text { excellence }\end{array}$ & $\begin{array}{l}\text { The competitive standing or rating of a } \\
\text { software producer compared with rival } \\
\text { software organisations. } \\
\text { Defined as the strategic quality driver for } \\
\text { selecting a suitable producer. }\end{array}$ & $\begin{array}{l}\text { - Regional affiliation } \\
\text { - Financial capacity } \\
\text {-Experience }\end{array}$ \\
\hline $\begin{array}{l}\text { Corporate } \\
\text { accreditation }\end{array}$ & $\begin{array}{l}\text { The independent certification of the } \\
\text { producer organisation's capability of } \\
\text { creating quality software products. } \\
\text { Defined as the strategic quality driver of } \\
\text { contractor maturity. }\end{array}$ & $\begin{array}{l}\text { - CMM appraisal } \\
\text { •ISO certification }\end{array}$ \\
\hline $\begin{array}{l}\text { Domain } \\
\text { speciality }\end{array}$ & $\begin{array}{l}\text { The producer organisation's knowledge } \\
\text { and expertise of the procurer } \\
\text { organisation's business processes. } \\
\text { Defined as the strategic quality driver for } \\
\text { excellent business process } \\
\text { understanding. }\end{array}$ & $\begin{array}{l}\text {-Business process consultant } \\
\text { expertise }\end{array}$ \\
\hline $\begin{array}{l}\text { Development } \\
\text { excellence }\end{array}$ & $\begin{array}{l}\text { Ensuring that the software product is } \\
\text { created in accordance with best } \\
\text { management standards and practice. } \\
\text { Defined as the strategic quality driver for } \\
\text { excellence during the project life cycle. }\end{array}$ & $\begin{array}{l}\text {-Project management excellence } \\
\text { - Technical competence } \\
\text {-Continuous process improvement }\end{array}$ \\
\hline $\begin{array}{l}\begin{array}{l}\text { Quality } \\
\text { management }\end{array} \\
\text { Direction }\end{array}$ & $\begin{array}{l}\text { Ensuring that the procurer's quality } \\
\text { requirements are incorporated at all } \\
\text { phases of the evolving software product. } \\
\text { Defined as the strategic quality driver for } \\
\text { excellence in assuring software quality. }\end{array}$ & $\begin{array}{l}\text {-Quality manager } \\
\text { • Quality planning and control }\end{array}$ \\
\hline
\end{tabular}

Figure 3 - Strategic quality drivers defined - Producer 


\section{Conclusion}

This paper has presented the Software Quality - Strategic Driver Model ( $S Q-S D M)$ and has explained the different drivers that impact the procurer and producer of software products. While some of the Strategic Drivers are already well researched, others are new so this paper presents a comprehensive set and model based on the contractual processes of ISO/IEC 12207. While devised and explained in relation to software quality the foundation of the model is generic and it might be easily adapted to any specific domain in a specified context. In these domains and contexts it might be used by management to identify and manage the strategic drivers of interest to their selected domain. In addition to its importance to suppliers and acquirers of software products, the Strategic Driver Model presented in this paper is an excellent foundation for the academic syllabus for the study of software quality.

\section{References}

[1]. McCall, J., Richards, P. and Walters, G (1977) Factors in software quality, Vols I-III, Rome Aid Defence Centre, Italy

[2]. Boëhm, B. (1978) Characteristics of software quality, Vol 1 of TRW series on software technology, North-Holland, Amsterdam, Netherlands

[3]. Ghezzi, C., Jazayeri, M. and Mandrioli, D. (1991) Fundamentals of software engineering, Prentice-Hall, New Jersey, USA

[4]. ISO/IEC 12207 (1995) International Standard. Information technology - Software life cycle processes, International Organisation for Standardisation, Genève, Switzerland

[5]. Fitzpatrick, R. and Higgins, C. (1998). Usable software and its attributes: A synthesis of software quality, European Community law and human-computer interaction, In: People and Computers XIII. Proceedings of HCI'98 Conference, Springer, London, UK

[6]. Henderson, J. and Venkatraman, H. (1989) Strategic Alignment: A model for organizational transformation via Information technology, Working Paper 3223-90, Sloan Management Review

[7]. Eardley, W.A. (2000) SLIM/SLIP: a Proposed Method for Linking a Business Strategy to Strategic IS/IT Applications. $\mathrm{PhD}$ Thesis, University of Southampton, UK

[8]. Weill, P . and Olson, M.H. (1989) Managing investments in Information Technology, mini case examples and implications, MIS Quarterly, 13(1), p3-18
[9]. Robson, W. (1994) Strategic management and information systems:an integrated approach, Pitman Publishing, London, UK

[10]. Porter, M. E. (1980) Competitive Strategy: Techniques for analyzing industries and competitors, Free Press

[11]. Porter, M.E. (1985) Competitive Advantage, Free Press.

[12]. Paulk, Mark C., Curtis, Bill, Chrissis, Mary Beth and Weber, Charles V. (1993b) "Capability Maturity Model, Version 1.1," IEEE Software, Vol. 10, No. 4, July 1993, pp. 18-27. (http://www.sei.cmu.edu/activities/cmm/cmm.articles.html)

[13]. ISO Standard 9001 (1994) Quality Systems - Model for quality assurance in design, development, production, installation and servicing, International Organisation for Standardisation, Genève, Switzerland

[14]. ISO 9000-3 (1997) International Standard. Quality management and quality assurance standards - part 3:Guidelines for the application of ISO 9001:1994 to the development, supply, installation and maintenance of computer software, International Organisation for Standardisation, Genève, Switzerland

[15]. 2WCSQ (2000) Proceeding of the Second World Congress for Software Quality, Union of Japanese Scientists and Engineers, Tokyo, Japan 